\title{
Pengaruh Current Ratio, Return On Equity, dan Total Asset Turnover Terhadap Earning Per Share (Studi Empiris: Pada Perusahaan Sektor Kertas Dan Pulp Yang Terdaftar Pada Bursa Efek Indonesia Periode Tahun 2013 - 2017)
}

\author{
${ }^{1}$ Wahyu Abadi, ${ }^{2}$ Hermansyah \\ ${ }^{1,2}$ Institut Ilmu Sosial dan Manajemen STIAMI \\ Email: ${ }^{1}$ skripsiwahyuabadi@gmail.com, ${ }^{2}$ hermansyah.chan@gmail.com
}

\section{ARTICLE INFO}

Keywords

On Equity,

Total Asset Turn Over,

Earning Per Share,

Paper,

Pulp

\begin{abstract}
The purpose of the research is to examine the influence of Current Ratio, Return On Equity, and Total Asset Turn Over on Earning Per Share. The sample of this research is a paper and pulp companies listed on the Indonesia Stock Exchange period 2013 - 2017 as much as 4 companies in 5 period. Data collected from financial report from year ended 2013 - 2017. This research is used quantitative approach with a type of correlational research. This research using multiple linier regression methods with the SPSS version 24 Programs. The results of the analysis show that as simultaneously, the Current Ratio, Return On Equity, and Total Asset Turn Over have a significant effect on Earning Per Share. It showed by significant value of F-test 0,000 lower than 0,05 .
\end{abstract}

\section{PENDAHULUAN}

Kertas dan pulp di Indonesia memiliki potensi yang sangat besar untuk berkembang. Kebutuhan kertas di masa mendatang masih tetap tinggi, seiring dengan langkah pengurangan penggunaan plastik sekali buang. Ini membuat harga kertas tak terbendung.

Untuk saat ini, pertumbuhan kebutuhan kertas dunia utamanya didorong negara di kawasan Asia, seperti China dan India. Besarnya populasi di kedua negara tersebut mendorong tingginya tingkat konsumsi kertas dan tisu. Buktinya, kini penyerapan kertas di Asia mencapai 52\% dari total kebutuhan dunia.

Untuk saat ini, kunci dari kinerja emiten sektor pulp dan kertas ini adalah harga kertas. Hal ini dikarenakan China baru saja merilis peraturan mengenai Environmental Protection Controls, yaitu kebijakan yang membatasi jumlah impor kertas olahan, harga bubur kertas pun menjadi naik.

Kenaikan harga kertas, akan memperbaiki kinerja keuangan pada sektor kertas dan pulp sehingga akan meningkatkan nilai Earning Per Share nya. EPS atau Earning Per Share digunakan sebagai bahan pertimbangan oleh calon investor dalam investasi di pasar modal, maka perlu dianalisis lebih lanjut.

\section{Ruang Lingkup Penelitian}

Berdasarkan latar belakang dan identifikasi masalah diatas maka penelitian ini dibatasi pembahasannya mengenai: Current Ratio, Return On Equity, dan Total Asset Turn Over untuk menganalisis pengaruhnya terhadap Rasio Earning Per Share agar penelitian ini lebih fokus dan mendalam.

\section{Perumusan Masalah}

Berdasarkan uraian latar belakang diatas perumusan masalah yang dapat diambil ialah: 
1. Seberapa besar pengaruh Current Ratio terhadap Earning Per Share di perusahaan sektor kertas dan pulp yang terdaftar di BEI tahun 2013 - 2017?

2. Seberapa besar pengaruh Return On Equityterhadap Earning Per Share di perusahaan sektor kertas dan pulp yang terdaftar di BEI tahun $2013-2017$ ?

3. Seberapa besar pengaruh Total Assets Turnover terhadap Earning Per Share di perusahaan sektor kertas dan pulp yang terdaftar di BEI tahun $2013-2017$ ?

4. Seberapa besar pengaruh Current Ratio, Return On Equity, dan Total Assets Turnover terhadap Earning Per Share di perusahaan sektor kertas dan pulp yang terdaftar di BEI tahun 2013 - 2017?

\section{Tujuan Penelitian}

Berdasarkan rumusan masalah diatas penelitian ini bertujuan untuk mengetahui seberapa besar:

1. Pengaruh Current Ratio terhadap Earning Per Share di perusahaan sektor kertas dan pulp yang terdaftar di BEI tahun 2013 - 2017

2. Pengaruh Return On Equity terhadap Earning Per Share di perusahaan sektor kertas dan pulp yang terdaftar di BEI 2013 - 2017

3. Pengaruh Total Asset Turn Over terhadap Earning Per Share di perusahaan sektor kertas dan pulp yang terdaftar di BEI 2013 - 2017

4. Pengaruh Current Ratio, Return On Equity, dan Total Asset Turn Over terhadap Earning Per Share di perusahaan sektor kertas dan pulp yang terdaftar di BEI 2013 - 2017

\section{KAJIAN LITERATUR}

\section{Kinerja Keuangan}

Menurut Fahmi (2012:2) "Kinerja keuangan adalah suatu analisis yang dilakukan untuk melihat sejauh mana suatu perusahaan telah melaksanakan dengan menggunakan aturan - aturan pelaksanaan keuangan secara baik dan benar".

Tujuan pengukuran kinerja keuangan penting untuk diketahui karena pengukuran yang dilakukan dapat mempengaruhi perilaku pengambilan keputusan dalam perusahaan. Pengukuran kinerja keuangan suatu perusahaan tergantung pada sudut pandang yang diambil dan di analisis.

Oleh karena itu, pihak manajemen perusahaan sangat perlu menyesuaikan kondisi perusahaan dengan alat ukur penilaian kinerja yang akan digunakan serta tujuan pengukuran kinerja keuangan tersebut

\section{Hubungan Rasio Keuangan dan Kinerja Keuangan}

Pada dasarnya rasio keuangan dan kinerja keuangan memliki hubungan yang sangat erat. Rasio keuangan banyak jumlahnya dan setiap rasio itu mempunyai kegunaannya masing - masing.

Bagi investor, akan melihat rasio dengan penggunaan yang paling sesuai dengan analisis yang akan dilakukan. Jika rasio tersebut tidak merepresentasikan tujuan dari analisis yang akan ia lakukan maka rasio tersebut tidak dipergunakan, karena dalam konsep keuangan dikenal dengan fleksibilitas, artinya rumus atau berbagai bentuk formula yang dipergunakan haruslah disesuaikan dengan kasus yang diteliti.

\section{Current Ratio}

Rasio Lancar atau Current Ratio (CR) merupakan rasio untuk mengukur kemampuan perusahaan dalam membayar kewajiban jangka pendek atau utang yang segera jatuh tempo pada saat ditagih keseluruhan. Selanjutnya variabel ini disebut dengan CR dapat dihitung dengan cara : (Kasmir, 2015:134) 


$$
\text { Current Ratio }=\frac{\text { Current Assets }}{\text { Current Liabilities }}
$$

\section{Return On Equity}

Return On Equity (ROE) merupakan rasio untuk mengukur laba bersih sesudah pajak dengan modal sendiri. Rasio ini menunjukkan efisiensi penggunaan modal sendiri. "Semakin tinggi rasio ini, semakin baik. Artinya posisi pemilik perusahaan semakin kuat, demikian pula sebaliknya" (Kasmir 2015:204). Adapun ROE dapat dirumuskan sebagai berikut :

$$
\text { Return On Equity }(R O E)=\frac{\text { Earning After Tax }(E A T)}{\text { Equity }}
$$

\section{Total Asset Turn Over}

Total Assets Turn Over adalah rasio yang digunakan untuk mengukur perputaran semua aktiva yang dimiliki perusahaan dan mengukur berapa jumlah penjualan yang diperoleh dari tiap rupiah aktiva. Selanjutnya variabel ini disebut dengan TATO dapat dihitung dengan cara:

$$
\text { Total Assets Turnover }(\text { TATO })=\frac{\text { Net Sales }}{\text { Total Assets }}
$$

\section{Earning Per Share}

EPS adalah perbandingan antara laba bersih dengan seluruh jumlah lembar saham biasa yang beredar. Variabel EPS dinyatakan dengan lambang EPS. Variabel EPS digunakan untuk menunjukkan kemampuan perusahaan untuk memberikan imbalan (return) pada setiap lembar saham biasa.

$$
\text { Earning Per Share }=\frac{\text { Laba Bersih }- \text { deviden saham preferen }}{\text { Jumlah Lembar Saham Biasa }}
$$

\section{Hipotesis}

Berdasarkan teori dan kerangka pemikiran yang dijelaskan sebelumnya, maka dapat dirumuskan hipotesis penelitian sebagai berikut:

1. Terdapat pengaruh yang signifikan Current Ratio terhadap Earning Per Share secara parsial pada perusahaan sektor Kertas dan Pulp yang terdaftar di BEI tahun 2013 - 2017

2. Terdapat pengaruh yang signifikan Return On Equity terhadap Earning Per Share secara parsial pada perusahaan sektor Kertas dan Pulp yang terdaftar di BEI tahun 2013 - 2017

3. Terdapat pengaruh yang signifikan Total Assets Turnover terhadap Earning Per Share secara parsial pada perusahaan sektor Kertas dan Pulp yang terdaftar di BEI tahun 2013 - 2017

4. Terdapat pengaruh yang signifikan Current Ratio, Return On Equity dan Total Asset Turnover Terhadap Earning Per Share secara simultan pada perusahaan sektor Kertas dan Pulp yang terdaftar di BEI tahun $2013-2017$ 


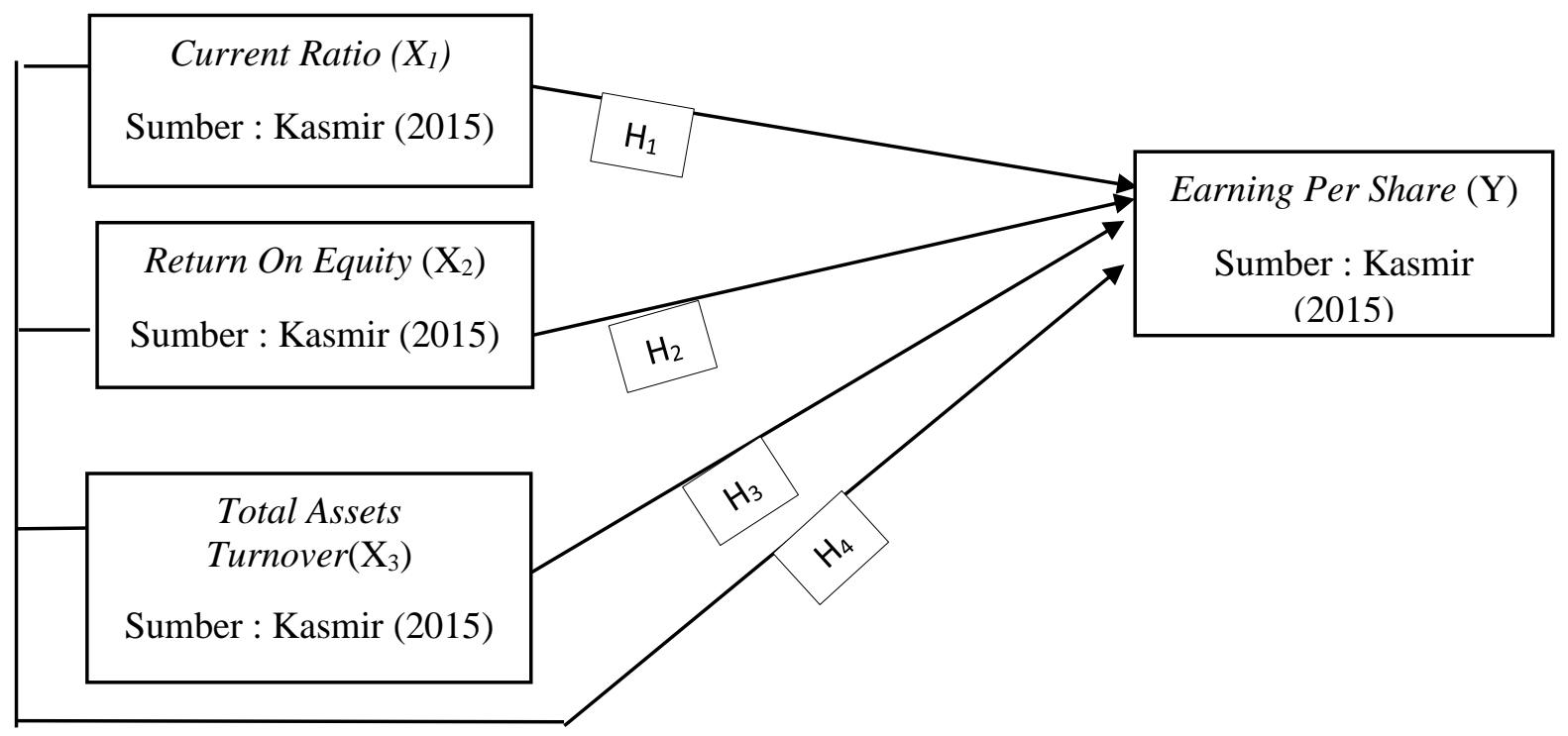

\section{METODE PENELITIAN}

\section{Pendekatan Penelitian}

Penelitian ini menggunakan pendekatan kuantitatif dengan jenis penelitian korelasional yaitu suatu penelitian yang melibatkan kegiatan pengumpulan data untuk menentukan, adakah hubungan dan tingkat hubungan antara 2 variabel atau lebih. Penelitian korelasi dilakukan, saat penelitian ingin mengetahui tentang ada atau tidaknya dan kuat lemahnya suatu hubungan variabel yang berkaitan dalam suatu objek atau subjek yang diteliti.

\section{Teknik Pengumpulan Data}

Data yang digunakan pada penelitian kali ini yaitu data sekunder. Data sekunder merupakan data tidak langsung memberikan data kepada pengumpulan data. Sumber data yang digunakan dalam penelitian ini adalah dari berbagai sumber buku, laporan keuangan, dan jurnal penelitian terdahulu yang dapat mendukung penelitian ini. Sedangkan untuk sumber data yang akan diolah dalam analisis penelitian adalah dari situs web resmi Bursa Efek Indonesia www.idx.co.id.

\section{Teknik Sampling}

populasi pada penelitian kali ini yaitu berupa perusahaan sektor kertas dan pulp yang terdaftar di Bursa Efek Indonesia. Metode sampling yang digunakan yaitu Purposive Random Sampling dengan kriteria sebagai berikut:

1. Perusahaan sektor kertas dan pulp yang terdaftar di Bursa Efek Indonesia

2. Memiliki IPO (Initial Public Offering) paling akhir tahun 2012 dan mempublikasikan laporan keuangannya selama 5 tahun berturut - turut.

3. Perusahaan tidak mengalami kerugian selama periode berjalan. 
Tabel 1

Daftar Sampel Penelitian

\begin{tabular}{|c|c|l|}
\hline No & Kode Saham & \multicolumn{1}{|c|}{ Nama Emiten } \\
\hline 1 & ALDO & Alkindo Naratama, Tbk \\
\hline 2 & INKP & Indah Kiat Pulp \& paper, Tbk \\
\hline 3 & KDSI & Kedawung Setia Industrial, Tbk \\
\hline 4 & TKIM & Pabrik Kertas Tjiwi Kimia, Tbk \\
\hline
\end{tabular}

Sumber:Sahamok.com (Data Diolah Penulis)

\section{Variabel Penelitian}

Variabel terikat yang digunakan pada penelitian ini yaitu Earning Per Share (EPS), sedangkan Variabel bebasnya yaitu Current Ratio, Return On Equity, dan Total Asset Turn Over.

\section{Metode Analisis Data}

Rancangan analisis merupakan langkah - langkah yang dilakukan dalam menganalisis data dengan menggunakan soft ware SPSS versi 24 dengan metode regresi linier berganda.

\section{Uji Statistik Deskriptif}

Statistik deskriptif memberikan gambaran atau deskripsi mengenai suatu data yang dapat menggambarkan pola sebaran data sehingga mampu untuk digunakan dalam mengambil kesimpulan.

2. Uji Asumsi Klasik

Uji asumsi klasik adalah pengujian asumsi-asumsi statistik pada analisis regresi linear berganda berbasis ordinary least square (OLS) yang bertujuan untuk mengetahui apakah model estimasi telah memenuhi kriteria.

a. Uji Normalitas

Uji normalitas bertujuan untuk menguji kenormalan distribusi variabel penggangu atau residual. Jika asumsi ini dilanggar, maka uji statistik menjadi tidak valid atau bias terutama untuk sampel kecil (Ghozali, 2016:161).

b. Uji Multikolinieritas

Uji multikolinieritas bertujuan untuk menguji apakah dalam model regresi terdapat korelasi antara variabel bebas. Model regresi yang baik adalah ketika tidak ada korelasi diantara variabel bebasnya. Multikolinieritas dapat dilihat dari nilai tolerance dan variance inflation factor (VIF). Nilai cutoff yang digunakan adalah nilai tolerance $<0,10$ atau $\mathrm{VIF}>10$.

c. Uji Heterokedastisitas

Uji heteroskedestisitas bertujuan untuk menguji apakah dalam model regresi terjadi ketidaksamaan varians dari residual satu pengamatan ke pengamatan yang lain. Jika varians residualnya tetap maka disebut homokedastisitas dan jika berbeda disebut heterokedastisitas

d. Uji Linieritas

Uji linearitas digunakan untuk melihat apakah spesifikasi model yang digunakan sudah benar atau tidak. Dengan uji linearitas akan diperoleh informasi apakah model empiris sebaiknya linear, kuadrat atau kubik. 
e. Uji Autokorelasi

Uji ini bertujuan untuk menguji apakah model regresi linear terdapat korelasi antara kesalahan pengganggu pada periode $t$ dengan kesalahan pengganggu pada periode $\mathrm{t}-1$ (sebelumnya). Jika terjadi korelasi, maka dinamakan ada problem korelasi

3. Uji Hipotesis

Uji hipotesis dalam penelitian ini menggunakan analisisregresi berganda, uji koefisien determinasi, uji statistik t dan ujistatistik F. Uji Hipotesis tersebut secara lebih jelas diuraikan sebagai berikut :

a. Uji Regresi Linier Berganda

Analisis regresi linier berganda digunakan untuk meramalkan bagaimana keadaan (naik turunnya) variabel terikat (kriterium), bila dua atau lebih variabel bebas sebagai faktor prediktor dimanipulasi (dinaik turunkan nilainya). Jadi analisis regresi ganda akan dilakukan bila jumlah variabel bebas nya minimal 2 (Sugiyono, 2016:277).

b. Uji Koefisien Korelasi

Analisis korelasi bertujuan untuk mengukur kekuatan asosiasi (hubungan) linear antara dua variabel. Korelasi tidak menunjukkan hubungan fungsional atau dengan kata lain analisis korelasi tidak membedakan antara variabel terikat dengan variabel bebas (Ghozali,2016:93-94)

c. Uji Signifikansi Parameter Individual t (Uji t)

Uji statistik t menunjukkan seberapa jauh pengaruh satu variabel bebas secara individual dalam menerangkan variasi variabel terikat. (Ghozali, 2016:98). Apabila nilai signifikansi $<0,05$ maka terdapat pengaruh yang signifikan secara parsial antara variabel bebas terhadap variabel terikat.

d. Uji Signifikan Simultan (Uji Statistik F)

Pengujian signifikansi persamaan dilakukan dengan menggunakan uji $\mathrm{F}$ yang bertujuan untuk mengetahui apakah varibel bebas secara bersama-sama mempengaruhi variabel terikat nya.

e. Uij Koefisien Determinasi

Menurut Ghozali (2016:95) Koefisien determinasi $\left(\mathrm{R}^{2}\right)$ mengukur seberapa jauh kemampuan model dalam menerangkan variasi variabel dependen.

\section{HASIL PENELITIAN DAN PEMBAHASAN}

\section{Hasil Penelitian}

1. Uji Statistik Deskriptif

Untuk memperoleh gambaran secara menyeluruh tentang variabel-variabel yang digunakan dalam penelitian ini baik variabel terikat maupun variabel bebas, maka dilakukan terlebih dahulu analisis secara statistik deskriptif yang mencakup nilai rata-rata (mean), standar deviasi, dan nilai ekstrim (nilai maksimum dan nilai minimum). Berikut ini rangkuman data statistik deskriptif dari variabel-variabel yang di gunakan dalam penelitian ini seperti yang ditunjukkan pada Tabel 2:

Tabel 2

Hasil Analisis Statistik Deskriptif

\begin{tabular}{|c|c|c|c|c|c|c|}
\hline Variabel & N & Range & Minimum & Maximum & Mean & $\begin{array}{c}\text { Std. } \\
\text { Deviation }\end{array}$ \\
\hline CR & 20 & 106,32 & 115,66 & 221,98 & 147,9855 & 27,9318 \\
\hline ROE & 20 & 16,00 & 0,15 & 16,15 & 8,5645 & 5,0573 \\
\hline TATO & 20 & 135,56 & 39,12 & 174,68 & 97,8005 & 59,21069 \\
\hline EPS & 20 & 1025,56 & 2,86 & 1028,42 & 203,3520 & 269,8344 \\
\hline
\end{tabular}

Sumber : Hasil Output SPSS 24 (Data diolah Penulis) 
Dari hasil deskriptif diatas memperlihatkan bahwa pertumbuhan Earning Per Share (Y), Current Ratio $\left(\mathrm{X}_{1}\right)$, Return On Equity $\left(\mathrm{X}_{2}\right)$, dan Total Assets Turn Over $\left(\mathrm{X}_{3}\right)$ cenderung meningkat yang ditunjukkan oleh nilai rata - rata hitung (mean) yang bernilai positif 147,9855 untuk Current Ratio $\left(\mathrm{X}_{1}\right)$; 8,5645 untuk Return On Equity ( $\left.\mathrm{X}_{2}\right)$; 97,8005 untuk Total Asset Turn Over $\left(\mathrm{X}_{3}\right)$; dan 203,3520 untuk Earning Per Share (Y).

Sementara itu untuk sebaran data yang ditunjukkan oleh perbedaan nilai maksimum dan minimum menunjukkan sebaran yang lebih luas dimana nilai maksimum tertinggi terjadi pada variabel Y (Earning Per Share) dan nilai maksimum terendah pada variabel $\mathrm{X}_{2}$ (Return On Equity). Sedangkan untuk nilai minimum tertinggi terjadi pada variabel $\mathrm{X}_{1}$ (Current Ratio) dan nilai minimum terendah terjadi pada variabel $\mathrm{X}_{2}$ (Return On Equity).

2. Uji Asumsi klasik

a. Uji Normalitas

Uji normalitas bertujuan untuk menguji apakah model regresi dan variabel bebas dan terikat mempunyai distribusi yang normal atau tidak.

Tabel 3

Hasil Uji Statistik Normalitas Kolmogorov-smirnov

One-Sample Kolmogorov-Smirnov Test

\begin{tabular}{|llr|}
\hline \multicolumn{1}{|l}{} & \multicolumn{2}{c}{ Unstandardized Residual } \\
\hline Normal & & 20 \\
Parameters ${ }^{\mathrm{a}, \mathrm{b}}$ & Mean &, 0000000 \\
\cline { 2 - 3 } & Std. & Deviation \\
Most Extreme & Absolute &, 171 \\
\cline { 2 - 3 } Differences & Positive &, 171 \\
\cline { 2 - 3 } & Negative &,- 108 \\
\hline Test Statistic & &, 171 \\
\hline Asymp. Sig. (2-tailed) &, $127^{\mathrm{c}}$ \\
\hline
\end{tabular}

a. Test distribution is Normal.

b. Calculated from data.

c. Lilliefors Significance Correction.

Sumber : Hasil Output SPSS 24 (diolah penulis)

Berdasarkan tabel 3 hasil Output SPSS diatas, diketahui bahwa nilai signifikansi Asymp. Sig. (2tailed) sebesar 0,127 lebih besar dari 0,05. Maka sesuai dengan dasar pengambilan keputusan dalam uji Kolmogorov-smirnov diatas, dapat disimpulkan bahwa data berdistribusi normal. Dengan demikian, asumsi atau persyaratan normalitas dalam regresi sudah terpenuhi.

b. Uji Multikolinieritas

Model regresi yang baik seharusnya tidak terjadi korelasi diantara variabel bebas. Deteksi terhadap ada tidaknya multikolonieritas dalam penelitian ini dengan :

1) Menganalisis matrik korelasi antar variabel bebas, jika antar variabel bebas ada korelasi yang cukup tinggi (umumnya diatas 0,90 ) maka hal ini merupakan indikasi adanya multikolonieritas,

2) Melihat nilai tolerance dan nilai variance inflation factor, suatu model regresi yang bebas dari masalah multikolonieritas 


\section{Tabel 4}

Hasil Uji Multikolinieritas

\begin{tabular}{|c|c|c|c|}
\hline Variabel & Tolerance & VIF & Keterangan \\
\hline CR & $0,695>0,10$ & $1,440<10$ & Tidak Terjadi Multikolineritas \\
\hline ROE & $0,570>0,10$ & $1,738<10$ & Tidak Terjadi Multikolineritas \\
\hline TATO & $0,431>0,10$ & $2,321<10$ & Tidak Terjadi Multikolineritas \\
\hline
\end{tabular}

Sumber : Hasil Output SPSS 24 (Diolah Penulis)

Berdasarkan tabel 4 diatas nilai VIF pada masing - masing variabel < (kurang dari) 10 dan nilai tolerance nya pada masing - masing variabel adalah $>0,10$. Dengan hasil yang diperoleh variabel Current Ratio $\left(\mathrm{X}_{1}\right)$, Return On Equity $\left(\mathrm{X}_{2}\right)$, dan Total Asset Turn Over $\left(\mathrm{X}_{3}\right)$ terhadap Earning Per Share (Y) tidak terjadi multikolineritas dan lolos uji multikolinieritas.

c. Uji Heterokedastisitas

Uji heterokedastisitas bertujuan untuk menguji apakah dalam model regresi terjadi ketidaksamaan varians dari residual satu pengamatan ke pengamatan yang lain. Jika varians dari satu residual pengamatan ke pengamatan lain tetap, maka disebut homokedastisitas dan jika varians berbeda disebut heterokedastisitas. Model regresi yang baik adalah yang homokedastisitas atau tidak terjadi heterokedastisitas (Ghozali, 2016:134).

Tabel 5

Hasil Uji Heterokedastisitas

\begin{tabular}{|c|c|c|c|}
\hline Variabel & Nilai signifikansi & Kriteria Pengujian & Kesimpulan \\
\hline CR & 0,371 & $0,371>0,05$ & Bebas Heterokedastisitas \\
\hline ROE & 0,622 & $0,622>0,05$ & Bebas Heterokedastisitas \\
\hline TATO & 0,439 & $0,439>0,05$ & Bebas Heterokedastisitas \\
\hline
\end{tabular}

Sumber : Hasil Output SPSS 24 (data diolah penulis)

Berdasarkan tabel 5 diatas, nilai signifikansi hitung masing - masing variabel adalah lebih dari $<0,05$ hal ini menunjukkan model diatas bebas heterokedastisitas.

Pengujian lain dalam uji heterokedastisitas selain menggunakan uji glejser yaitu dengan melihat grafik plot (ZPRED) dengan residualnya (SRESID). Dengan dasar pengambilan keputusan sebagai berikut :

1) Jika ada pola tertentu, seperti titik-titik yang ada membentuk pola tertentu yang teratur (bergelombang, melebar kemudian menyempit), maka mengindikasi telah terjadi heteroskedastisitas.

2) Jika tidak ada pola yang jelas, serta titik-titik menyebar diatas dan di bawah angka 0 pada sumbu Y, maka tidak terjadi heteroskedastisitas. 


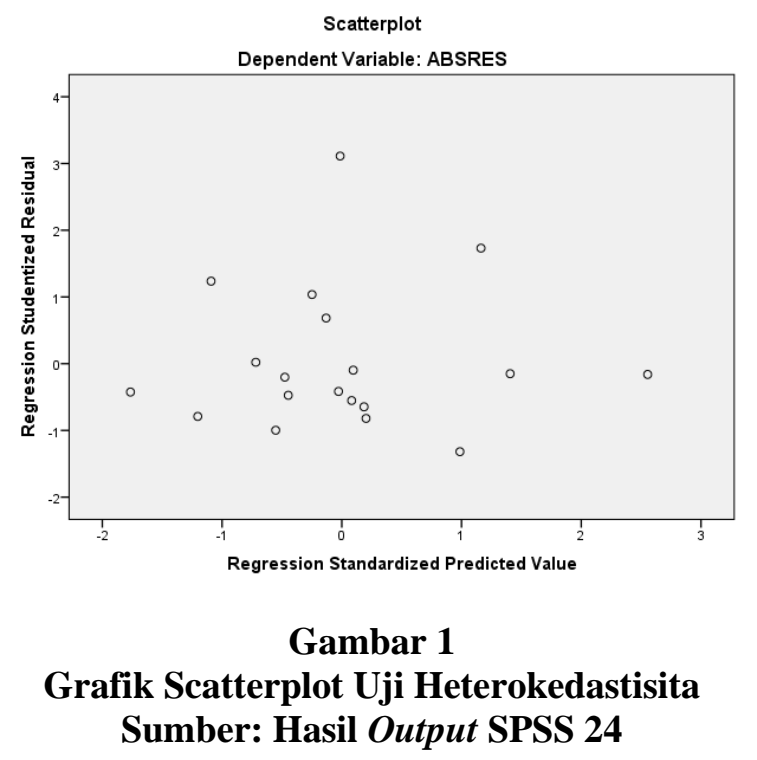

Gambar Scatter plot memiliki pola yang tidak jelas, serta titik-titik menyebar di atas dan di bawah angka 0 pada sumbu $Y$, hal ini dapat disimpulkan bahwa dalam penelitian ini tidak terjadi heterokedastisitas. Sehingga model regresi layak digunakan untuk memprediksi Pengaruh Current Ratio, Return On Equity, dan Total Asset Turn Over terhadap Earning Per Share

d. Hasil Uji Linieritas

Bertujuan untuk mengetahui spesifikasi model yang digunakan sudah benar atau tidak. Apakah fungsi yang digunakan dalam suatu studi empiris berbentuk linear, kuadrat atau kubik (Ghozali, 2011:166). Cara yang pertama adalah membandingkan nilai $\mathrm{F}$ hitung dengan tabel. Apabila harga $\mathrm{F}$ hitung kecil atau sama dengan $\mathrm{F}$ tabel maka hubungan variabel bebas (X) dengan variabel terikat (Y) dinyatakan linear.

Tabel 6

Hasil Uji Linieritas CR, ROE, TATO terhadap EPS ANOVA $^{\mathrm{a}}$

\begin{tabular}{llc|c|c|c|c} 
& Model & Sum of Squares & df & Mean Square & F & Sig. \\
\hline \multirow{2}{*}{1} & Regression & 833208,711 & 3 & 277736,045 & 8,150 &, $002^{\mathrm{b}}$ \\
\cline { 2 - 8 } & Residual & 550193,510 & 16 & 34387,068 & & \\
\cline { 2 - 8 } & Total & 1383401,221 & 19 & & & \\
\hline
\end{tabular}

a. Dependent Variable: EPS

b. Predictors: (Constant), TATO, ROE, CR

Sumber : Hasil Output SPSS 24 (data diolah penulis)

Dari tabel 6 diatas diperoleh probabilitas (tingkat signifikansi) 0,002. Oleh karena probabilitas $0,000<$ dari 0,05 , sehingga dapat dapat dapat dikatakan terdapat pengaruh yang signifikan antara variabel Current Ratio $\left(\mathrm{X}_{1}\right)$, Return On Equity $\left(\mathrm{X}_{2}\right)$, dan Total Asset Turn Over $\left(\mathrm{X}_{3}\right)$ secara bersama sama (simultan) terhadap variabel Earning Per Shares $(\mathrm{Y})$ di sektor kertas dan pulp yang terdaftar di BEI tahun 2013 - 2017. Dikatakan signifikan karena nilai sig. 0,002 < dari tingkat signifikan yang digunakan dalam penelitian 0,05

e. Hasil Uji Autokorelasi

Pengujian ini bertujuan untuk menguji apakah model regresi linier terdapat korelasi antara kesalahan pengganggu pada periode pengujian saat ini dengan periode sebelumnya Jika terjadi korelasi, maka dinamakan ada problem korelasi. autokorelasi terjadi karena ada obervasi yang berurutan sepanjang waktu berkaitan satu dengan yang lainnya 
Tabel 7

Hasil Uji Autokorelasi

\begin{tabular}{|l|c|r|r|r|r|}
\multicolumn{7}{|c|}{ Model Summary } \\
\hline Model & R & R Square & $\begin{array}{c}\text { Adjusted R } \\
\text { Square }\end{array}$ & $\begin{array}{l}\text { Std. Error of } \\
\text { the Estimate }\end{array}$ & $\begin{array}{l}\text { Durbin- } \\
\text { Watson }\end{array}$ \\
\hline 1 &, $860^{\mathrm{a}}$ &, 740 &, 688 & 132,75624 & 2,148 \\
\hline
\end{tabular}

a. Predictors: (Constant), TATO, CR, ROE

b. Dependent Variable: EPS

Sumber : Hasil Output SPSS 24 (Data diolah Penulis)

Pada pengujian tabel 7 diatas didapat nilai Durbin Watson pada tabel adalah $\mathrm{d}_{\mathrm{U}}$ 1,6763 $(\mathrm{k}=3, \mathrm{~N}=20)$ dan $\mathrm{d}_{\mathrm{L}}$ 0,9976 $(\mathrm{k}=3, \mathrm{~N}=20)$. Dari tabel 7 diatas diperoleh nilai hitung durbin-watson sebesar 2,148 nilai ini kemudian dibandingkan dengan dU tabel sebesar 1,6763 dan dL tabel sebesar 0,9976. Adapun syarat dari bebas autokorelasi adalah dimana nilai hitung durbin-watson lebih besar dari dU tabel dan kurang dari $4-\mathrm{dU}$ tabel atau secara matematis dirumuskan $\mathrm{dU}<\mathrm{d}<4-\mathrm{dU}$. Nilai hitung durbin-watson diatas telah memenuhi syarat bebas autokorelasi. Maka dapat disimpulkan model diatas bebas autokorelasi.

3. Hasil Uji Hipotesis

a. Hasil Uji Regresi Linier Berganda

Tabel 8

Hasil Uji Regresi Linier Berganda

Coefficients $^{\mathrm{a}}$

\begin{tabular}{|c|c|c|c|c|c|c|}
\hline \multirow{2}{*}{\multicolumn{2}{|c|}{ Model }} & \multicolumn{2}{|c|}{$\begin{array}{l}\text { Unstandardized } \\
\text { Coefficients }\end{array}$} & \multirow{2}{*}{$\begin{array}{c}\text { Standardized } \\
\text { Coefficients } \\
\text { Beta } \\
\end{array}$} & \multirow[b]{2}{*}{$\mathrm{t}$} & \multirow[b]{2}{*}{ Sig. } \\
\hline & & $\mathrm{B}$ & Std. Error & & & \\
\hline \multirow[t]{4}{*}{1} & (Constant) & 66,423 & 139,064 & & ,478 & ,640 \\
\hline & $\mathrm{CR}$ & ,776 & 1,667 & ,066 & ,466 & ,648 \\
\hline & ROE & 54,584 & 9,727 & ,924 & 5,612 & ,000 \\
\hline & TATO & $-4,775$ &, 962 &,- 841 & $-4,963$ & ,000 \\
\hline
\end{tabular}

a. Dependent Variable: EPS

Sumber : Hasil Output SPSS 24 (Data diolah Penulis)

Adapun persamaan regresi pada penelitian kali ini yaitu sebagai berikut :

EPS $=\beta \alpha+\beta_{1} \mathrm{CR}+\beta_{1} \mathrm{ROE}+\beta_{1}$ TATO

EPS $=66,423+0,776 \mathrm{CR}+54,584 \mathrm{ROE}-4,775 \mathrm{TATO}$

Dari persamaan regresi yang dihasilkan maka, diperoleh interprestasi sebagai berikut:

1) Konstanta sebesar 66,423 menyatakan bahwa jika Current Ratio, Retun On Equity dan Total Assets Turn Over (Variabel bebas) dianggap konstan, maka nilai Earning Per Share adalah $66,423$.

2) Koefisien regresi Current Ratio sebesar 0,776 menyatakan bahwa jika setiap kenaikan Current Ratio sebesar satu nilai, sementara variabel lainnya bernilai tetap. Maka, Earning Per Share akan mengalami kenaikan sebesar 0,776

3) Koefisien regresi Return On Equity sebesar 54,584 menyatakan bahwa jika setiap kenaikan Return On Equity sebesar satu nilai, sementara variabel lainnya bernilai tetap. Maka, Earning Per Share akan mengalami kenaikan sebesar 54,584 
4) Koefisien regresi Total Asset Turn Over sebesar -4,775 menyatakan bahwa jika setiap kenaikan Total Asset Turn Over sebesar satu nilai, sementara variabel lainnya bernilai tetap. Maka, Earning Per Share akan mengalami penurunan sebesar 4,775

b. Hasil Uji Signifikansi parameter individual t (uji t)

Uji t dalam penelitian ini digunakan untuk menguji hipotesis penelitian yaitu untuk mengetahui pengaruh variabel bebas yaitu Current Ratio, Return On Equity, dan Total Asset Turn Over terhadap variabel terikat yaitu Earning Per Share. Hasil uji ini dikatakan berpengaruh signifikan apabila nilai sig $<0,05$ dan nilai $t_{\text {hitung }}>t_{\text {tabel}}$,

Tabel 9

Hasil Uji t CR, ROE, dan TATO terhadap EPS

Coefficients $^{\mathrm{a}}$

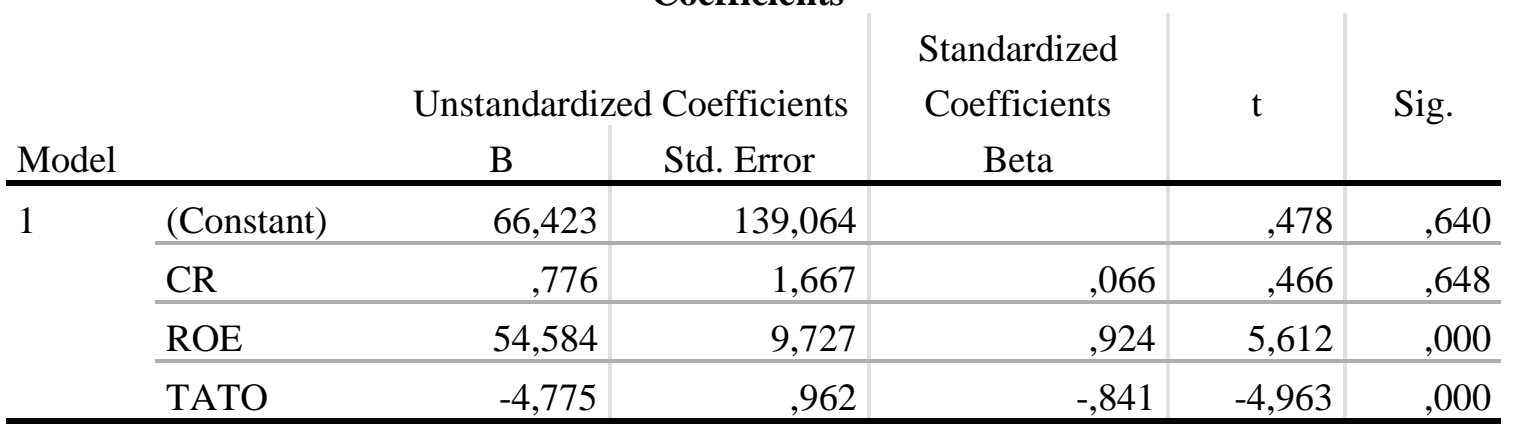

a. Dependent Variable: EPS

Sumber : Hasil Output SPSS 24 (Data diolah Penulis)

Berdasarkan tabel 9 diatas, dapat disimpulkan bahwa:

1) Current Ratio $\left(\mathrm{X}_{1}\right)$ nilai dari thitung sebesar 0,466 lebih kecil dari tabel dengan signifikansi 0,05 $\mathrm{df}=16$ (two tailed) 2,11991 dalam hal ini variabel CR berpengaruh positif dan tidak signifikan terhadap EPS. Sehingga $\mathrm{H}_{0}$ diterima dan $\mathrm{H}_{1}$ ditolak

2) Return On Equity nilai dari $t_{\text {hitung }}$ sebesar 5,612 lebih besar dari $t_{\text {tabel }}$ dengan signifikansi 0,05 $\mathrm{df}=16$ (two tailed) 2,11991 dalam hal ini variabel ROE berpengaruh positif dan signifikan terhadap EPS. Sehingga $\mathrm{H}_{2}$ diterima dan $\mathrm{H}_{0}$ ditolak

3) Total Asset Turn Over nilai dari thitung sebesar -4,963 lebih besar tetapi bernilai negative dari $t_{\text {tabel }}$ dengan signifikansi $0,05 \mathrm{df}=16$ (two tailed) 2,11991 dalam hal ini variabel TATO berpengaruh negatif dan signifikan terhadap EPS. Sehingga $\mathrm{H}_{3}$ diterima dan $\mathrm{H}_{0}$ ditolak.

c. Uji Signifikansi F (Uji F)

Pengujian ini dilakukan untuk mengetahui apakah variabel bebas secara keseluruhan mempunyai pengaruh terhadap variabel terikat. Uji hipotesis ini membandingkan antara nilai $\mathrm{F}_{\text {hitung }}$ pada keyakinan tertentu.

Tabel 10

Hasil Uji Regresi ANOVA

\begin{tabular}{|c|c|c|c|c|c|c|}
\hline \multicolumn{7}{|c|}{ ANOVA $^{a}$} \\
\hline Model & & $\begin{array}{l}\text { Sum of } \\
\text { Squares }\end{array}$ & df & Mean Square & $\mathrm{F}$ & Sig. \\
\hline \multirow[t]{3}{*}{1} & Regression & 751827,826 & 3 & 250605,942 & 14,219 &, $000^{\mathrm{b}}$ \\
\hline & Residual & 264363.282 & 15 & 17624,219 & & \\
\hline & Total & 1016181,108 & 18 & & & \\
\hline
\end{tabular}

a. Dependent Variable: EPS

b. Predictors: (Constant), TATO, ROE, CR

Sumber : Hasil Output SPSS 24 (Data diolah Penulis)

Berdasarkan tabel 10 di atas, hasil Uji $\mathrm{F}$ dapat dilihat bahwa $\mathrm{F}_{\text {hitung }} 14,219$ dan nilai $\mathrm{F}_{\text {tabel }}$ sebesar 3,24 dengan signifikan 0,000 kurang dari 0,05. Sehingga dapat disimpulkan bahwa nilai

Wahyu Abadi, et.al (Pengaruh Current Ratio, Return On Equity, dan Total Asset Turnover...) 
$\mathrm{F}_{\text {hitung }}$ lebih besar dari $\mathrm{F}_{\text {tabel }}$ sehingga dapat ditarik kesimpulan antara Current Ratio $\left(\mathrm{X}_{1}\right)$, Return On Equity $\left(\mathrm{X}_{2}\right)$, dan Total Asset Turn Over $\left(\mathrm{X}_{3}\right)$ secara simultan berpengaruh signifikan terhadap Earning Per Share (Y) pada perusahaan sub sektor kertas dan pulp yang terdaftar di BEI tahun $2013-2017$.

d. Uji Koefisien Determinasi

Uji koefisien determinasi $\left(\mathrm{R}^{2}\right)$ digunakan untuk mengukur seberapa jauh kemampuan model dalam menerangkan variasi variabel dependen. Analisis determinasi digunakan untuk mengetahui persentase sumbangan pengaruh variabel $\left(\mathrm{X}_{1}, \mathrm{X}_{2}\right.$, dan $\left.\mathrm{X}_{3}\right)$ secara bersama-sama terhadap variabel dependen (Y).

\section{Tabel 11}

\section{Hasil Uji Koefisien Determinasi $\left(\mathbf{R}^{2}\right)$}

\begin{tabular}{|c|c|c|c|c|}
\hline \multicolumn{5}{|c|}{ Model Summary $^{\text {b }}$} \\
\hline Model & $\mathrm{R}$ & R Square & Adjusted R Square & $\begin{array}{l}\text { Std. Error of the } \\
\text { Estimate }\end{array}$ \\
\hline 1 &, $860^{\mathrm{a}}$ & ,740 & 688 & 132,75624 \\
\hline
\end{tabular}

a. Predictors: (Constant), ROE, CR, TATO

b. Dependent Variable : EPS

Sumber : Hasil Output SPSS 24 (Data diolah Penulis)

Berdasarkan tabel 11 di atas, dapat diketahui bahwa koefisien determinasi (R Square) sebesar 0,740 atau 74\% yang artinya kontribusi Current Ratio, Return On Equity dan Total Asset Turn Over terhadap Earning Per Share sebesar 0,740 atau 74,00\% dan untuk sisanya 26\% dipengaruhi oleh variabel lain yang tidak diteliti oleh peneliti.

\section{Pembahasan \\ Pengaruh Current Ratio terhadap Earning Per Share}

Hasil penelitian menunjukkan bahwa Current Ratio berpengaruh positif dan tidak signifikan terhadap Earning Per Share. Pengaruh tersebut ditunjukkan dengan nilai dari $t_{\text {hitung }}=0,466$ sedangkan $t_{\text {tabel }}$ pada signifikan 0,05 yaitu sebesar 2,119. Maka nilai $t_{\text {hitung }}$ lebih kecil dari $t_{\text {tabel }}$, dalam hal ini berarti variabel Current Ratio $\left(\mathrm{X}_{1}\right)$ berpengaruh positif tetapi tidak signifikan terhadap Earning Per Share (Y) pada perusahaan sektor kertas dan pulp yang terdaftar di Bursa Efek Indonesia pada tahun 2013 - 2017. Dengan koefisien regresi bernilai positif (+) sebesar 0,776, dalam persamaan regresi EPS $=66,423+0,776 \mathrm{CR}+$ 54,584 ROE - 4,775 TATO. Tanda positif ini mempunyai arti bahwa setiap kenaikan Current Ratio akan diikuti peningkatan Earning Per Share.

Hal tersebut sejalan dengan penelitian yang dilakukan oleh Kumala Shinta, dkk (2014) yang mengkaji salah satu variabel yaitu Current Ratio terhadap Earning Per Share dengan nilai signifikansi pada taraf 5\% sebesar 0,679>0,05 maka menunjukkan bahwa Current Ratio berpengaruh positf tetapi tidak signifikan terhadap Earning Per Share.

\section{Pengaruh Return On Equity Terhadap Earning Per Share}

Hasil penelitian menunjukkan bahwa Return On Equity memiliki pengaruh positif yang signifikan positif terhadap Earning Per Share. Pengaruh tersebut ditunjukkan dengan nilai dari thitung $=5,612$ sedangkan $\mathrm{t}_{\text {tabel }}$ pada signifikan 0,05 yaitu sebesar 2,119. Maka nilai $\mathrm{t}_{\text {hitung }}$ lebih besar dari $\mathrm{t}_{\text {tabel }}$, dalam hal ini berarti variabel Return On Equity $\left(\mathrm{X}_{2}\right)$ memiliki pengaruh positif dan signifikan terhadap Earning Per Share (Y) pada perusahaan sektor kertas dan pulp yang terdaftar di Bursa Efek Indonesia pada tahun 2013 - 2017.

Hal ini sejalan dengan penelitian yang dilakukan oleh Barlianta Uno, dkk (2014) yang mengkaji salah satu variabel yaitu Return On Equity terhadap Earning Per Share dengan signifikansi 0,001 < 0,05 menunjukkan bahwa Return On Equity berpengaruh positif dan signifikan terhadap Earning Per Share.

\section{Pengaruh Total Asset Turn Over Terhadap Earning Per Share}

Hasil penelitian menunjukkan bahwa Total Assets Turn Over berpengaruh negatif dan signifikan terhadap Earning Per Share. Pengaruh tersebut ditunjukkan dengan nilai dari $t_{\text {hitung }}=-4,963$ sedangkan $t_{\text {tabel }}$ 
pada signifikan 0,05 yaitu sebesar 2,119. Maka nilai $t_{\text {hitung }}$ lebih besar dari $t_{\text {tabel }}$, dalam hal ini berarti variabel Total Asset Turn Over $\left(\mathrm{X}_{3}\right)$ memiliki pengaruh yang signifikan terhadap Earning Per Share (Y) pada perusahaan sektor kertas dan pulp yang terdaftar di Bursa Efek Indonesia pada tahun 2013 - 2017. Nilai negatif (-) pada koefisien regresi berarti bahwa setiap Kenaikan Total Asset Turn Over akan berdampak pada penurunan pada Earning Per Share pada perusahaan sektor kertas dan pulp yang terdaftar di Bursa Efek Indonesia tahun $2013-2017$.

Hal ini sejalan dengan penelitian yang dilakukan oleh Sutejo (2009) yang juga mengkaji salah satu variabel yang mempengaruhi Earning Per share. Yang menunjukkan bahwa Total Asset Turn Over memiliki pengaruh terhadap Earning Per Share.

\section{Pengaruh Current Ratio, Return On Equity, dan Total Asset Turn Over terhadap Earning Per Share}

Hasil penelitian menunjukkan bahwa Current Ratio, Return On Equity, dan Total Asset Turn Over berpengaruh signifikan terhadap Earning Per Share. Pengaruh tersebut dapat dilihat dari hasil Uji F dapat dilihat bahwa $F_{\text {hitung }} 14,219$ dan nilai $F_{\text {tabel }}$ sebesar 3,240 dengan signifikan 0,000 kurang dari 0,05. Sehingga dapat disimpulkan bahwa nilai $\mathrm{F}_{\text {hitung }}$ lebih besar dari $\mathrm{F}_{\text {tabel }}$ sehingga dapat ditarik kesimpulan bahwa $\mathrm{H}_{0}$ ditolak $\mathrm{H}_{1}$ diterima. Yang berarti antara Current Ratio $\left(\mathrm{X}_{1}\right)$, Return On Equity $\left(\mathrm{X}_{2}\right)$, dan Total Asset Turn Over $\left(\mathrm{X}_{3}\right)$ secara simultan berpengaruh signifikan terhadap Earning Per Share (Y) pada perusahaan sektor kertas dan pulp yang terdaftar di Bursa Efek Indonesia tahun 2013 - 2017.

Hasil penelitian ini mendukung hasil penelitian yang dilakukan oleh Kumala Shinta (2014) yang mengkaji pengaruh kinerja keuangan, ukuran perusahaan dan arus kas operasi terhadap Earning Per Share pada perusahaan sektor manufaktur. Menunjukkan bahwa CR, ROE, dan TATO berpengaruh positif terhadap Earning Per Share. Hal ini juga menguatkan penelitian yang juga dilakukan oleh Sutejo dan Ubud Salim (2009) dalam penelitiannya tentang analisis variabel yang mempengaruhi Earning Per Share pada perusahaan sektor Food and Bevarages. Menunujukkan bahwa variabel CR, ROE, dan TATO berpengaruh positif terhadap Earning Per Share.

\section{KESIMPULAN DAN SARAN}

\section{Kesimpulan}

Berdasarkan hasil penelitian dan pembahasan pada bab sebelumnya, maka dapat ditarik kesimpulan sebagai berikut:

1. Berdasarkan hasil penelitian diatas, terbukti bahwa Current Ratio (CR) tidak berpengaruh positif tetapi tidak signifikan terhadap Earning Per Share (EPS). Hal tersebut dibuktikan melalui uji t, dimana t hitung lebih kecil daripada t tabel $(0,466<2,11991)$

2. Berdasarkan hasil penelitian diatas, terbukti bahwa Return On Equity (ROE) memiliki pengaruh positif dan signifikan terhadap Earning Per Share (EPS). Hal tersebut dibuktikan melalui uji t, dimana t hitung lebih besar daripada $t$ tabel dan bernilai positif $(5,612>2,11991)$

3. Berdasarkan hasil penelitian diatas, terbukti bahwa Total Asset Turn Over (TATO) memiliki pengaruh negatif dan signifikan terhadap Earning Per Share (EPS). Hal tersebut dibuktikan melalui uji t, dimana t hitung lebih besar daripada $t$ tabel dan bernilai negatif $(-4,963>2,11991)$

4. Berdasarkan hasil uji koefisien regresi, didapatkan bahwa Current Ratio, Return On Equity dan Total Asset Turn Over memberikan pengaruh terhadap Earning Per Share sebesar 66,423 dalam persamaan regresi sebagai berikut, EPS $=66,423+0,776 \mathrm{CR}+54,584 \mathrm{ROE}-4,775$ TATO. Hal itu menyatakan bahwa, jika Current Ratio, Return On Equity dan Total Asset Turn Over dianggap konstan, maka Earning Per Share adalah 66,423. Selain itu, berdasarkan hasil uji koefisien determinasi (R square), sebesar 0,740 atau 74\% yang artinya secara simultan (bersama - sama) Current Ratio, Return On Equity dan Total Asset Turn Over dapat menjelaskan variasi dari variabel terikat yaitu Earning Per Share sebesar 0,74 atau $74 \%$ dan untuk sisanya $26 \%$ dipengaruhi oleh variabel lain yang tidak diteliti oleh peneliti.

Wahyu Abadi, et.al (Pengaruh Current Ratio, Return On Equity, dan Total Asset Turnover...) 


\section{Saran}

Penelitian ini masih membutuhkan beberapa item perbaikan untuk dilakukan pada penelitian-penelitian selanjutnya yang memiliki keterkaitan dengan objek penelitian yang sejenis sehingga dapat menjadikan penelitian ini lebih baik. Adapun beberapa saran perbaikan adalah sebagai berikut.

1. Bagi akademis dan peneliti selanjutnya sebaiknya:

a. Menggunakan metode penelitian lain dalam rangka mengkonfirmasi hasil penelitian kuantitatif ini untuk memberikan hasil mengenai hubungan antara rasio kinerja keuangan terhadap Earning Per Share.

b. Mengembangkan penelitian dengan menambah variabel lainnya seperti Inventory Turn Over dan lain - lain, sehingga hasil penelitian yang didapatkan lebih meluas dari penelitian sebelumnya.

2. Bagi para praktisi pelaku investasi saham di Bursa Efek Indonesia, penelitian ini dapat dijadikan refrensi dalam menganalisa emiten sebelum melakukan penanaman modal di pasar modal

3. Bagi pemegang kepentingan perusahaan sub sektor kertas dan pulp yang dijadikan sebagai sampel dalam penelitian ini, penelitian ini dapat dijadikan sebagai bahan refrensi untuk penentu kebijakan kedepannya dalam meningkatkan penjualan dan laba, sehingga dapat meningkatkan investor di emiten terkait.

\section{DAFTAR PUSTAKA}

Fahmi. Irham. 2017. Analisis Kinerja Keuangan. Bandung : CV Alfabeta

Ghozali. Imam. 2018. Aplikasi Analisis Multivariate dengan Program IBMSPSS 25 edisi 9. Semarang : Badan Penerbit - Undip

Hanafi, Mahmud dan Halim, Abdul. 2016. Analisis Laporan Keuangan edisi Kelima. Yogyakarta: UPP STIM YKPN

Harahap, Sofyan Safri. 2010. Teori Akuntansi, Edisi Revisi 2010. Jakarta : PT Raja Grafindo Persada

Ikatan Akuntansi Indonesia. PSAK No. 1 Tentang Laporan Keuangan-edisi revisi 2015. Penerbit Dewan Standar Akuntansi Keuangan: PT Raja Grafindo

Werren Carls S., Reeve James M., et al. 2017. Pengantar Akuntansi. Alih Bahasa: Amir Abadi Jusuf. Jakarta: Salemba Empat.

Weygandt, Kimmel and kieso. 2013. Financial Accounting: IFRS Edition. Hoboken: John Wiley \& Sons, Inc www.idx.co.id 